\title{
Akses ke Sarana Sanitasi Dasar sebagai Faktor Risiko Kejadian Stunting pada Balita Usia 6-59 Bulan
}

\author{
Amrul Hasan ${ }^{1}$, Haris Kadarusman ${ }^{2}$ \\ Jurusan Kesehatan Lingkungan, Politeknik Kesehatan Tanjung Karang, Indonesia \\ Email: amrulhasan@gmail.com
}

\begin{abstract}
Access to Basic Sanitation Facilities as a Risk Factor The Incidence of Stunting in Toddlers Aged 6-59 Months. Stunting is a condition of failure to thrive in children under five (infants under five years old) due to chronic malnutrition so children are too short for their age. Toddlers are short (stunted) and very short (severely stunted) are toddlers with body length (PB/U) or height (TB/U) according to their age compared to WHO-2010 standard. The research objective was to analyze the relationship between Access to Basic Sanitation Facilities and Stunting Events in children aged 6-59 months in East Lampung Regency. The study using a case-control design with a population was all children aged 6 to 59 months in nine stunting locus villages in the Regency East Lampung in 2018. Cases are 200 stunting children, controls are 200 children in normal status. Cases were taken from nine villages which were designated as stunting loci, while controls were normal toddlers who were in one integrated healthcare center with cases. Data collection by interview and measurement and observation. Univariate, bivariate data analysis, and multivariate (multiple logistic regression test). The results of the multivariate analysis found two variables related to the incidence of stunting, namely access to healthy latrines OR 5,99 (95\%CI:2,98-9,23), Access to clean water sources OR=5,99 (95\% CI:3,31-10,83), after being controlled by variable history of infectious diseases, history of MPASI administration and history of growth monitoring. Access to healthy latrines and access to clean water sources that meet health requirements is a risk factor for stunting after adjusting for the variable history of infectious disease, history of MPASI administration, history of growth monitoring.
\end{abstract}

Keywords: Access to healthy latrines, Access to clean water sources, Stunting

Abstrak: Akses ke Sarana Sanitasi Dasar sebagai Faktor Risiko Kejadian Stunting pada Balita Usia 6-59 Bulan. Stunting merupakan kondisi gagal tumbuh pada anak balita (bayi di bawah lima tahun) akibat dari kekurangan gizi kronis sehingga anak terlalu pendek untuk usianya. Balita pendek (stunted) dan sangat pendek (severely stunted) adalah balita dengan panjang badan $(\mathrm{PB} / \mathrm{U})$ atau tinggi badan $(\mathrm{TB} / \mathrm{U})$ menurut umurnya dibandingkan dengan standar baku WHO2010. Tujuan penelitian menganalisis hubungan antara akses terhadap sarana sanitasi dasar dengan kejadian stunting pada balita usia 6-59 bulan di Kabupaten Lampung Timur Tahun 2018. Penelitian menggunakan desain kasus kontrol dengan populasi adalah seluruh anak usia 6 sampai 59 bulan di sembilan desa lokus stunting di Kabupaten Lampung Timur Tahun 2018. Kasus 200 balita stunting, kontrol adalah 200 balita status normal. Kasus diambil dari sembilan desa yang ditetapkan sebagai lokus stunting, sedangkan kontrol adalah balita normal yang berada satu posyandu dengan kasus. Pengumpulan data dengan wawancara dan pengukuran dan observasi. Analisis data univariat, bivariat (uji kai kuadrat), dan multivariat (uji regresi logistik ganda). Hasil analisis bivariat menemukan delapan variabel yang berhubungn dengan kejadian stunting. Hasil analisis multivatiat didapatkan dua variabel yang berhubungan dengan kejadian stunting yaitu akses ke jamban sehat OR=5,99 (95\% CI: 2,98-9,23), akses ke sumber air bersih OR=5,99 (95\% CI: 3,31-10,83), setelah dikontrol dengan variabel riwayat penyakit infeksi, riwayat pemberian MPASI dan riwayat pemantauan pertumbuhan. Akses ke jamban sehat dan akses ke sumber air bersih yang memenuhi syarat kesehatan merupakan faktor risiko stunting setelah disesuaikan dengan variabel riwayat penyakit infeksi, riwayat pemberian MPASI, riwayat pemantauan pertumbuhan.

Kata kunci: Akses ke jamban sehat, Akses ke sumber air bersih, Stunting 


\section{PENDAHULUAN}

Stunting merupakan kondisi gagal tumbuh pada anak balita (bayi di bawah lima tahun) akibat dari kekurangan gizi kronis sehingga anak terlalu pendek untuk usianya. Kekurangan gizi terjadi sejak bayi dalam kandungan dan pada masa awal setelah bayi lahir akan tetapi, kondisi stunting baru nampak setelah bayi berusia 2 tahun.

Menurut World Health Organization (WHO), prevalensi balita pendek menjadi masalah kesehatan masyarakat jika prevalensinya $20 \%$ atau lebih, karenanya persentase balita pendek di Indonesia masih tinggi dan merupakan masalah kesehatan yang harus ditanggulangi. Prevalensi balita pendek di Indonesia juga tertinggi dibandingkan Myanmar (35\%), Vietnam $(23 \%)$, Malaysia (17\%), Thailand $(16 \%)$ dan Singapura (4\%). (WHO, 2016)

Di Indonesia, sekitar 37\% (hampir 9 Juta) anak balita mengalami stunting (Riset Kesehatan Dasar, 2013) dan di seluruh dunia, Indonesia adalah negara dengan prevalensi stunting kelima terbesar. Balita/baduta (bayi di bawah usia Dua Tahun) yang mengalami stunting akan memiliki tingkat kecerdasan tidak maksimal, menjadikan anak menjadi lebih rentan terhadap penyakit dan di masa depan dapat berisiko pada menurunnya tingkat produktivitas.

Kejadian balita stunting (pendek) merupakan masalah gizi utama yang dihadapi Indonesia. Berdasarkan data Pemantauan Status Gizi (PSG) selama tiga tahun terakhir, pendek memiliki prevalensi tertinggi dibandingkan dengan masalah gizi lainnya seperti gizi kurang, kurus, dan gemuk. Prevalensi balita pendek mengalami peningkatan dari tahun 2016 yaitu 27,5\% menjadi 29,6\% pada tahun 2017 (Tim Nasional Percepatan Penanggulangan Kemiskinan, 2017).

Stunting disebabkan oleh faktor multi dimensi dan tidak hanya disebabkan oleh faktor gizi buruk yang dialami oleh ibu hamil maupun anak balita. Intervensi yang paling menentukan untuk dapat mengurangi prevalensi stunting oleh karenanya perlu dilakukan pada 1.000 Hari Pertama Kehidupan (HPK) dari anak balita. (Kementerian Kesehatan RI, 2018)

Menurut Prendergast, A. J., \& Humphrey, J.H (2014), faktor risiko stunting dapat dikategorikan ke dalam beberapa kondisi yakni keadaan ibu/wanita usia subur, keadaan bayi, dan keadaan lingkungan. Kondisi tersebut secara singkat dijelaskan sebagai berikut:

a. Ibu hamil yang Kurang Energi Kronis (KEK) dan menderita anemia, b. Bayi yang tidak mendapat Air Susu Ibu (ASI) eksklusif,

c. Makanan Pendamping ASI (MPASI) yang tidak tepat,

d. Pertumbuhan yang tidak dipantau,

e. Penyediaan air bersih dan sanitasi yang tidak layak.

Penelitian Torlesse, et al (2016) di Indonesia menemukan bahwa kombinasi antara sanitasi yang tidak layak dan kualitas air minum yang tidak aman merupakan faktor risiko stunting. Penelitian lain yang di lakukan di 137 negara berkembang yang mengidentifikasi faktor-faktor risiko lingkungan (yaitu, kualitas air yang buruk, kondisi sanitasi yang buruk, dan penggunaan bahan bakar padat) memiliki pengaruh terbesar kedua pada kejadian Stunting secara global (Prendergast, A. J., \& Humphrey, J. $\mathrm{H}, 2014$ ).

Akses terhadap air bersih dan fasilitas sanitasi yang buruk dapat meningkatkan kejadian penyakit infeksi yang dapat membuat energi untuk pertumbuhan teralihkan kepada perlawanan tubuh menghadapi infeksi, gizi sulit diserap oleh tubuh dan terhambatnya pertumbuhan. Pada tahun 2017, 72,04\% rumah tangga di Indonesia memiliki akses terhadap sumber air minum layak. Provinsi dengan persentase tertinggi adalah Bali $(90,85 \%)$, sedangkan persentase terendah adalah Bengkulu $(43,83 \%)$. Masih terdapat 20 provinsi yang di bawah persentase nasional. Sumber air minum layak yang dimaksud adalah air minum yang terlindung meliputi air ledeng (keran), keran umum, hydrant umum, terminal air, penampungan air hujan (PAH) atau mata air dan sumur terlindung, sumur bor atau pompa, yang jaraknya minimal 10 meter dari pembuangan kotoran, penampungan limbah, dan pembuangan sampah. Persentase rumah tangga yang memiliki akses sanitasi layak di Indonesia tahun 2017 adalah $67,89 \%$. Provinsi dengan persentase tertinggi adalah DKI Jakarta (91,13\%), sedangkan persentase terendah adalah Papua $(33,06 \%)$ (BPS, 2017). Masih buruknya kondisi sanitasi di Indonesia merupakan isu penting yang berhubungan dengan meningkatnya risiko penyakit infeksi yang dapat menyebabkan stunting.

Kabupaten Lampung Timur Merupakan salah satu dari 3 (tiga) kabupaten di Provinsi Lampung yang menjadi prioritas pemerintah dalam penanggulangan masalah stunting (Tim Nasional Percepatan Penanggulangan Kemiskinan, 2017). Akses terhadap sarana sanitasi dasar di Kabupaten Lampung Timur masih rendah, 56 desa yang telah 
mendeklarisikan sebagai desa SBS dari 256 desa yang ada. Penderita Stanting di Kabupaten Lampung Timur tertinggi di banding Kabupaten Lampung Tengah dan Lampung Selatan. Sehingga penulis merumuskan permasalahan sebagai berikut, apakah ada hubungan akses sarana sanitasi berhubungan dengan kejadian stunting di Kabupaten Lampung Timur (Dinas Kesehatan Kab. Lampung Timur, 2017).

Tingginya prevalensi stunting pada anak berusia 6-59 bulan di desa lokus stunting di kabupaten Lampung Timur, perlu diteliti lebih lanjut untuk mengetahui faktor risiko apa saja yang berhubungan dengan kejadian stunting. Penelitian ini bertujuan untuk mengetahui hubungan akses sarana sanitasi dasar (jamban keluarga, sarana air bersih, sarana pembuangan air limbah, pengelolaan sampah, cuci tangan pakai sabun di air mengalir) dengan kejadian stunting di Kabupaten Lampung Timur.

Penelitian dapat dijadikan sebagai bahan masukan bagi pengelola program kesehatan lingkungan dan program gizi dalam menentukan tindakan untuk penanggulangan stunting.

\section{METODE}

Penelitian ini adalah jenis penelitian observasional menggunakan desain kasus kontrol untuk akses terhadap sarana sanitasi dasar dengan kejadian stunting pada balita usia 6-59 bulan di desa lokus stunting di Kabupaten Lampung Timur Tahun 2018. Penelitian ini dilakukan selama 6 (enam) bulan (Juli-Desember 2018) di 9 (sembilan) di Kabupaten Lampung Timur. Populasi adalah semua anak usia enam sampai 59 bulan (balita). Indeks anthropometry diukur berdasarkan parameter panjang/tinggi badan menurut usia dibandingkan dengan standar anthropometry referensi Keputusan Menteri Kesehatan No. 1995 tahun 2011. Balita usia kurang dari 24 bulan atau yang belum dapat berdiri diukur panjang badan dengan menggunakan length measuring board dalam posisi tidur. Sedangkan pada balita usia $\geq 24$ bulan dilakukan dalam posisi berdiri dengan menggunakan microtoice kapasitas ukur 2 meter dengan ketelitian $0,1 \mathrm{~cm}$. Kasus adalah balita dengan indeks panjang badan menurut umur atau tinggi badan menurut umur ( $<-2 \mathrm{SD})$ berstatus pendek (stunting) sebanyak 200 anak, sedangkan kontrol adalah balita memiliki indeks panjang badan menurut umur atau tinggi badan menurut umur ( $\geq-2$ SD) berstatus normal yang terdapat dalam satu posyandu dengan kasus sebanyak 200 anak. Responden adalah ibu dari balita pada kasus dan kontrol. Pemilihan kasus diawali dengan melakukan pengumpulan data hasil pengukuran tinggi badan dan mencatat tanggal lahir balita pada saat pelaksanaan posyandu, kemudian masukkan ke dalam aplikasi WHO anthro untuk mengetahui status balita. Hasil pengukuran kemudian ditentukan pemilihan Kasus dan Kontrol pada balita yang terdaftar di posyandu tersebut. Data Kepemilikan sarana sanitasi dasar dan faktor risiko lainnya diperoleh melalui wawancara menggunakan kuesioner dan melakukan observasi terhadap faktor lingkungan sedangkan Faktor anak meliputi riwayat berat dan panjang badan lahir, pemberian ASI dan Makanan Pendamping ASI (MPASI), penyakit infeksi, jenis kelamin, usia anak (Kementerian Kesehatan RI, 2011).

Pemberian ASI Ekslusif diukur dari riwayat memberikan ASI Ekslusif dari mulai lahir sampai berusia 6 bulan terus menerus tanpa makanan lain. Pemberian MPASI diukur dari riwayat memberikan MPASI sejak bayi berumur 6 bulan sampai saat dilaksanakan penelitian. terdiri dari beberapa pertanyaan tentang usia pemberian, jenis dan tahapan makanan pendamping ASI (MPASI) kemudian dari total skor dilakukan uji normalitas untuk dikategorikan menjadi baik dan kurang baik. Penyakit infeksi adalah suatu kondisi pada saat balita diukur mengalami gangguan karena terjadinya infeksi saluran pernapasan akut (ISPA), diare, atau campak selama penelitian dengan didasarkan pada diagnosis dokter. Riwayat pemantauan pertumbuhan berdasarkan perilaku ibu dalam memeriksakan bayi/balita ke posyandu.

Akses ke sarana sanitasi dasar di ukur berdasarkan kepemilikan dan penggunaan sarana sanitasi dasar yang memenuhi syarat kesehatan yaitu akses ke jamban sehat, akses ke sarana air bersih, kebiasaan mencuci tangan pakai sabun, pembuangan sampah dan pembuangan limbah.

Analisis data dilakukan secara bertahap di awali dengan analisis univariat, bivariat dan multivariat. Analisis univariat dengan menyajikan data dalam bentuk tabel distribusi frekuensi. Analisis bivariat digunakan untuk mengetahui sejauh mana hubungan antara akses terhadap sarana sanitasi dasar dan faktor risiko lain yang diduga berhubungan dengan stunting dilakukan dengan uji kai kuadrat dengan tingkat kemaknaan $(\alpha=0,05)$ dengan tingkat kepercayaan (CI) $95 \%$. Untuk mengetahui faktor risiko yang paling dominan dilakukan analisis multivariat dengan regresi logistik ganda terhadap variabel hasil analisis bivariat yang memiliki nilai $p$ value $<0,25$ atau secara substansi dianggap penting berhubungan terhadap stunting sehingga 
didapatkan model akhir dengan nilai $p$ value $\leq 0,05$ (Basuki B, 2000).

Penelitian ini telah mendapat keterangan kelaikan etik (ethical clearance) dari Komisi Etik
Penelitian Kesehatan Fakultas Kedokteran Universitas Lampung, Nomor: 208/EC/KEPTJK/VII/2018.

\section{HASIL}

Tabel 1. Distribusi Frekuensi, Karakteristik Kasus Dan Kontrol Balita Usia 6-59 Bulan

\begin{tabular}{|c|c|c|c|c|c|c|}
\hline \multirow{3}{*}{ Nama Variabel } & \multicolumn{4}{|c|}{ Status Responden } & \multirow{2}{*}{\multicolumn{2}{|c|}{ Total }} \\
\hline & \multicolumn{2}{|c|}{ Kontrol } & \multicolumn{2}{|c|}{ Kasus } & & \\
\hline & $\mathrm{n}=\mathbf{2 0 0}$ & $\%$ & $\mathrm{n}=\mathbf{2 0 0}$ & $\%$ & $n=400$ & $\%$ \\
\hline \multicolumn{7}{|l|}{ Jenis kelamin balita } \\
\hline Laki-laki & 86 & 43,00 & 109 & 54,50 & 195 & 48,75 \\
\hline Perempuan & 114 & 57,00 & 91 & 45,50 & 205 & 51,25 \\
\hline \multicolumn{7}{|l|}{ Akses ke jamban Sehat } \\
\hline Memenuhi syarat & 144 & 72,00 & 71 & 35,50 & 215 & 53,75 \\
\hline Tidak memenuhi syarat & 56 & 28,00 & 129 & 64,50 & 185 & 46,25 \\
\hline \multicolumn{7}{|c|}{ Cuci tangan pakai sabun di air mengalir } \\
\hline Memenuhi syarat & 149 & 74,50 & 81 & 40,50 & 230 & 57,50 \\
\hline Tidak memenuhi syarat & 51 & 25,50 & 119 & 59,50 & 170 & 42,50 \\
\hline \multicolumn{7}{|l|}{ Akses ke sumber air bersih } \\
\hline Memenuhi syarat & 114 & 57,00 & 42 & 21,00 & 156 & 39,00 \\
\hline Tidak memenuhi syarat & 86 & 43,00 & 158 & 79,00 & 244 & 61,00 \\
\hline \multicolumn{7}{|l|}{ Pengamanan sampah } \\
\hline Memenuhi syarat & 111 & 55,50 & 79 & 39,50 & 190 & 47,50 \\
\hline Tidak memenuhi syarat & 89 & 44,50 & 121 & 60,50 & 210 & 52,50 \\
\hline \multicolumn{7}{|l|}{ Pengamanan limbah rumahtangga } \\
\hline Memenuhi syarat & 145 & 73,23 & 118 & 59,00 & 263 & 66,08 \\
\hline Tidak memenuhi syarat & 53 & 26,77 & 82 & 41,00 & 135 & 33,92 \\
\hline \multicolumn{7}{|l|}{ Riwayat penyakit infeksi } \\
\hline Tidak pernah sakit & 174 & 87,00 & 108 & 54,00 & 282 & 70,50 \\
\hline Pernah sakit & 26 & 13,00 & 92 & 46,00 & 118 & 29,50 \\
\hline \multicolumn{7}{|l|}{ Riwayat pemberian ASI eksklusif } \\
\hline Mendapat ASI eksklusif & 136 & 68,00 & 85 & 42,50 & 221 & 55,25 \\
\hline Tidak ASI eksklusif & 64 & 32,00 & 115 & 57,50 & 179 & 44,75 \\
\hline \multicolumn{7}{|l|}{ Riwayat Pemberian MPASI } \\
\hline Mendapat MPASI & 132 & 66,00 & 78 & 39,00 & 210 & 52,50 \\
\hline Tidak mendapat MPASI & 68 & 34,00 & 122 & 61,00 & 190 & 47,50 \\
\hline \multicolumn{7}{|c|}{ Riwayat pemantauan pertumbuhan } \\
\hline Dipantau & 182 & 91,00 & 97 & 48,50 & 279 & 69,75 \\
\hline Tidak di pantau & 18 & 9,00 & 103 & 51,50 & 121 & 30,25 \\
\hline
\end{tabular}

Pada tabel 1 diketahui jumlah kasus yang berjenis kelamin perempuan lebih sedikit dibandingkan dengan kelompok kontrol, sebaliknya pada jenis kelamin laki-laki lebih banyak pada kelompok kasus.

Variabel independen lainnya (akses ke jamban keluarga, cuci tangan pakai sabun di air mengalir, akses ke sumber air bersih, pengamanan sampah, pengamanan limbah, riwayat penyakit infeksi, riwayat pemberian asi eksklusif, riwayat pemberian $\mathrm{mp}$ asi dan riwayat pemantauan pertumbuhan) pada kelompok kontrol dan kasus memiliki kondisi yang bertolak belakang. Pada kelompok kontrol seluruh variabel independen selain riwayat penyakit infeksi lebih banyak yang memenuhi syarat sedangkan pada kelompok kasus tidak ada riwayat penyakit infeksi, sedangkan pada kelompok kasus lebih banyak yang tidak memenuhi syarat. Riwayat penyakit infeksi pada kelompok kontrol maupun kelompok kasus lebih banyak tidak ada riwayat penyakit infeksi Analisis bivariat merupakan seleksi variabel independen sebagai kandidat yang akan masuk dalam analisis multivariat yaitu vatiabel yang memiliki nilai $p$-value $<0,25$ dan variabel yang secara substansi penting dan dianggap berhubungan dengan variabel dependen meskipun memiliki nilai $p$-value $>0,25$. Hasil analisis bi variat di laporkan bahwa seluruh variabel independen layak untuk di ikut sertakan ke dalam pemodelan multivariat, karena memiliki nilai $p$-avlue $<0,25$.

Analisis multivariat bertujuan melihat hubungan antara variabel independen dengan kejadian stunting di Kabupaten Lampung Timur 
setelah di kontrol dengan variabel independen lainnya, untuk mencapai tujuan ini digunakan analisis regresi logistik ganda, karena variabel dependennya berskala kategorik dan dikotomus.

Variabel penanganan dengan nila $p$ value $<0,05$, dikeluarkan secara bertahap sehingga didapat model variabel dengan nilai $p$ value $<0,05$. selanjutnya dilakukan penilaian potensial perancu. Penilaian adanya perancu berdasarkan perubahan relatif rasio odds. Hasil penilaian potensial perancu antara variabel independen penelitian (variabel independen) dengan variabel lainnya lain diperoleh 5 (lima) variabel perancu yaitu akses ke jamban sehat, akses ke sumber air bersih, riwayat penyakit infeksi, riwayat pemberian MPASI dan riwayat pemantauan pertumbuhan, didapatkan model akhir sebagaimana disajikan pada tabel 2 .

Tabel 2. Model Akhir Regresi Logistik Faktor Risiko yang Berhubungan dengan Kejadian Stunting

\begin{tabular}{lrrrrrrr}
\hline \multicolumn{1}{c}{ Subject } & Odds Ratio & Std. Err. & z & \multicolumn{1}{c}{ P> $|\mathbf{z}|$} & \multicolumn{2}{c}{$[\mathbf{9 5 \%}$ Conf. Interval] } \\
\hline Akses ke jamban sehat & 5,25 & 1,51 & 5,75 & 0,01 & 2,98 & - & 9,23 \\
Akses ke sumber air bersih & 5,99 & 1,81 & 5,92 & 0,01 & 3,31 & - \\
Riwayat penyakit infeksi & 4,42 & 1,44 & 4,57 & 0,01 & 2,34 & - \\
Riwayat pemberian MPASI & 3,69 & 1,05 & 4,61 & 0,01 & 2,12 & - \\
Riwayat Pemantauan Pertumbuhan & 10,16 & 3,52 & 6,70 & 0,01 & 5,16 & - & 6,43 \\
\hline
\end{tabular}

\section{PEMBAHASAN}

Penelitian ini bertujuan untuk mengetahui hubungan akses terhadap sarana sanitasi dasar dengan kejadian stunting di desa lokus stunting di Kabupaten Lampung Timur. Berdasarkan hasil analisis multivariat dilaporkan bahwa terdapat dua variabel lingkungan yang berhubungan dengan stunting di Kabupaten Lampung Timur yaitu akses ke jamban sehat dan akses ke sarana air bersih.

\section{Akses ke Jamban Sehat}

Akses ke jamban sehat berhubungan dengan kejadian stunting di Kabupaten Lampung Timur dengan $\mathrm{OR}=5,25 \quad(95 \% \mathrm{CI}: 2,98-9,23)$ artinya rumah tangga yang tidak memiliki akses ke jamban sehat, balitanya memiliki risiko untuk menderita stunting sebesar 5,25 untuk menderita stunting dibandingkan dengan keluarga yang memiliki akses ke jamban sehat setelah dikontrol dengan variabel akses ke sumber air bersih, riwayat penyakit infeksi, riwayat pemberian MPASI dan riwayat pemantauan pertumbuhan.

Fink, et al (2011), menampilkan hasil analisis dengan model yang tidak disesuaikan dan disesuaikan, sehingga memungkinkan untuk memastikan bagaimana perkiraan asosiasi antara peningkatan akses ke jamban yang memenuhi syarat kesehatan dan penurunan stunting setelah di kontrol dengan berbagai faktor individu, keluarga, dan komunitas. Lin, et al (2013), menyatakan akses ke jamban yang memenuhi syarat kesehatan berhubungan dengan penurunan risiko stunting dan ini asosiasi tetap setelah disesuaikan untuk kovariat, tetapi sedikit signifikan. Penelitian Rah, et al (2015), asosiasi antara penggunaan fasilitas toilet dan peluangnya stunting tetap signifikan setelah disesuaikan dengan berbagai kovariat rumah tangga, orang tua dan gizi. Fink, et al (2011), menemukan anak-anak yang memiliki akses ke Jamban Keluarga yang memenuhi syarat kesehatan secara signifikan dan jauh lebih rendah kemungkinan terhambat dibandingkan dengan anak-anak dengan "sanitasi yang berkualitas rendah", setelah di sesuaikan dengan kovariat. Hafid, dkk menemukan ada keterkaitan antara perilaku buang air besar, perilaku mencuci tangan menggunakan air mengalir/sabun, kejadian diare dengan kejadian stunting pada responden di Kabupaten Banggai dan Sigi (Hafid, F., \& Djabu, U, 2018).

Faktor lingkungan yang berisiko terhadap kejadian stunting pada balita adalah sanitasi lingkungan, hal ini sejalan dengan penelitian Van der Hoek, (2002), yang menyatakan bahwa anakanak yang berasal dari keluarga yang mempunyai fasilitas air bersih memiliki prevalensi diare dan stunting lebih rendah dari pada anak-anak dari keluarga yang tanpa fasilitas air bersih dan kepemilikan jamban.

Penurunan kejadian diare dapat dicapai melalui pendekatan komprehensif dengan mempromosikan praktik mencuci tangan, perawatan sarana penyimpanan air minum yang aman, pembuangan feses yang aman, dan kebersihan makanan; meningkatkan akses untuk teknologi dan produk-produk air dan sanitasi yang aman; dan memfasilitasi atau mendukung perbaikan sanitasi lingkungan (misalnya, perbaikan organisasi masyarakat, penguatan kelembagaan, dan kemitraan dengan sektor pemerintah maupun swasta) sehingga, kebersihan lingkungan dapat mengurangi paparan patogen yang berada di lingkungan pada anak-anak. 


\section{Akses ke Sumber Air Bersih}

Akses ke sumber air bersih berhubungan dengan kejadian stunting di Kabupaten Lampung Timur dengan $\mathrm{OR}=5.99 \quad$ (95\% CI:3,31-10,83) artinya keluarga yang tidak memiliki akses ke sumber air bersih balitanya memiliki risiko untuk menderita stunting sebesar 5,99 untuk menderita stunting dibandingkan dengan keluarga yang memiliki akses ke sumber air bersih setelah dikontrol dengan variabel akses ke jamban sehat, riwayat penyakit infeksi, riwayat pemberian MPASI dan riwayat pemantauan pertumbuhan.

Hasil penelitian ini sejalan dengan temuan studi observasional sebelumnya Lin et al, (2013), Rah, et al (2015), Fink, et al (2011), yang menemukan hubungan antara akses ke sarana air bersih dan jamban yang memenuhi syarat kesehatan dengan kejadian stunting di desa lokus stunting Kabupaten Lampung setelah disesuaikan dengan variabel riwayat penyakit infeksi, riwayat pemberian MPASI, riwayat pemantauan pertumbuhan. Checkley, et al (2005) menemukan anak-anak yang memiliki akses ke sumber air bersih yang rendah paling mungkin menderita stunting, setelah disesuaikan dengan variabel pendidikan ibu dan pendapatan rumah tangga. Sebaliknya, Rah et al. (2015), menemukan bahwa air leding tidak terkait dengan berkurangnya peluang terhambatnya pertumbuhan. Studi yang dilakukan oleh Lin, et al (2013), Rah, et al (2015).

Akses ke sarana sanitasi dasar terutama sarana air bersih dan jamban yang memenuhi syarat kesehatan akan berdampak pada kesehatan ketika keseimbangan tiga elemen berikut tercapai: 1) akses ke sarana sanitasi; 2) perubahan perilaku yang berkelanjutan dan 3) kebijakan yang mendukung kelembagaan lingkungan (misalnya, kebijakan peningkatas kapasitas kemitraan, pembiayaan dan motivasi masyarakat). Pemeliharaan sumber air bersih yang memenuhi syarat kesehatan di rumah tangga terbukti mengurangi risiko penyakit diare antara 30-40. Strategi sederhana dan murah dapat dilakukan untuk mengurangi kandungan mikroba air sehingga akan berdampak pada penurunan penyakit diare yang di iringi dengan buang air besar di jamban keluarga yang memenyhi syarat kesehatan dan mencuci tangan pakai sabun di air mengalir. Pengolahan air bersih di rumah dapat dilakukan dengan beberapa cara: merebus air sebelum diminum. Air yang telah di diolah harus disimpan dalam wadah yang bersih dan memiliki tutup. Berdasarkan hasil pembahasan yang telah dilakukan untuk mengendalikan faktor risiko stunting dapat dilakukan melalui peningkatan dan pemeliharaan sarana sanitasi dasar (Jamban Keluarga dan Sarana air bersih) di samping faktor lainnya yaitu praktik perilaku hidup bersih dan sehat (PHBS).

\section{Riwayat Penyakit Infeksi}

Persentase balita stunting yang memilliki riwayat penyakit infeksi lebih tinggi dibandigkan dengan balita normal di desa locus stunting di Kabupaten Lampung timur. Hal ini dikarenakan ibu pada balita kurang peduli terhadap kesehatan balitanya dan menganggap penyakit infeksi ini bukan menjadi hal yang serius. Hasil analisis multivariat ditemukan hubungan antara riwayat penyakit infeksi dengan kejadian stunting dengan OR 4,42 (95\%CI:2,34-8,36) setelah dikontrol variabel akses ke jamban sehat, Akses ke sumber air bersih, riwayat pemberian MPASI, riwayat pemantauan pertumbuhan. Penyakit infeksi mempunyai efek substansial terhadap pertumbuhan balita. Hal ini sesuai dengan penelitian Azmii (2018) menemukan hubungan antara riwayat penyakit infeksi dengan kejadian stunting nilai $p$-value $=0.006$.

Salah satu faktor penyebab terjadinya stunting adalah penyakit diare. Seorang anak yang mengalami diare akan terjadi malabsorbsi zat gizi dan hilangnya zat gizi dan bila tidak segera ditindaklanjuti dan diimbangi dengan asupan yang sesuai makan terjadi gagal tumbuh (Nasikhah, R, 2012). Infeksi dapat menyebabkan anak tidak merasa lapar dan tidak mau makan. Penyakit ini juga mengahabiskan sejumlah protein dan kalori yang seharusnya dipakai untuk pertumbuhan. Diare dan muntah dapat menghalangi penyerapan makanan. Penyakitpenyakit umum yang mernperburuk keadaan gizi adalah diare, infeksi saluran pemapasan atas, tuberculosis, campak, batuk rejan,malaria kronis dan cacingan. (Proverawati, A., \& Asfuah, S. (2009). Diare maupun infeksi pemapasan yang sering kambuh berkaitan dengan bentuk tubuh yang lebih pendek dalam masyarakat miskin di Negara berkernbang. Anak yang sehat pada umumnya akan tumbuh dengan baik, berbeda dengan anak yang sering sakit, biasanya pertumbuhannya akan terganggu karena menurunnya nafsu makan pada saat balita sakit. Melihat masalah yang ada, untuk itu diharapkan kepada ibu rumah tangga untuk memberikan dukungan asupan gizi yang adekuat agar balita terhindar dari penyakit infeksi. Selain itu, pemberian ASI pada anak sejak usia 6 bulan juga dapat menambah kekebalan tubuh anak sehingga terhindar dari bahaya penyakit infeksi (Antika dan Budiastutik, 2018). 
Kejadian penyakit infeksi yang tinggi, seperti diare dan ISPA, terhadap balita usia 6-59 bulan di desa lokus stunting di kabupaten Lampung Timur disebabkan karena kesadaran orang tua yang kurang akan pentingnya higiene dan sanitasi terhadap asupan gizi bagi anak. Pemahaman orang tua juga kurang dalam mempersiapkan kebutuhan pangan rumah tangga. Selain itu, penyebaran bakteri dan virus juga ditularkan melalui media atau orang-orang terdekat dari subjek penelitian. Faktor lingkungan, seperti sarana air yang tidak bersih juga menjadi penyebab terjadinya diare dan penyakit infeksi. Penyakit infeksi dan gangguan gizi seringkali ditemukan secara bersama-sama dan hubungannya saling mempengaruhi. Ada hubungan timbal balik antara asupan gizi dan kejadian infeksi. Kekurangan asupan berhubungan erat dengan tingginya kejadian penyakit diare, karena anak yang kurang gizi mungkin mengalami penurunan daya tahan tubuh dan dengan adanya penyakit infeksi menyebabkan anak tidak mempunyai nafsu makan. Akibatnya terjadi kekurangan makanan dan minuman yang masuk kedalam tubuh sehingga anak menderita kurang gizi (Supariasa, Bakri, dan Fajar, 2002).

\section{Riwayat Pemberian MP-ASI}

Makanan pendamping ASI (MP-ASI) adalah makanan yang diberikan kepada bayi setelah bayi berumur 6 bulan yang berfungsi untuk memberikan zat gizi tambahan selain dari ASI. Dengan bertambahnya umur bayi yang disertai kenaikan berat badan maupun tinggi badan, maka kebutuhan akan energi dan zat gizi lain akan bertambah pula. Kebutuhan gizi yang bertambah tidak bisa dipenuhi melalui ASI saja tapi juga melalui makanan pendamping. Makanan pendamping bagi bayi seharusnya menghasilkan energi sekurangkurangnya mengandung 360kkal per 100g bahan (Angkat, 2018).

Makanan pendamping ASI hendaknya padat gizi, dan mengandung serat kasar serta bahan lain yang sukar dicerna seminimal mungkin, sebab serat kasar yang terlalu banyak jumlahnya akan menganggu pencernaan. Makanan pendamping ASI juga tidak bisa cepat memberikan rasa kenyang pada bayi. Makanan pendamping ASI sebaiknya harus memenuhi persyaratan yaitu mengandung cukup energi dan protein; mengandung vitamin dan mineral dalam jumlah yang cukup dan dapat diterima dengan baik (Almatsier,2013). Pemberian makanan (MPASI) pada bayi hendaknya disesuaikan dengan perkembangan bayi. Misalnya bayi belajar mengunyah pada usia enam atau tujuh bulan, pada saat itu ia siap untuk mengkonsumsi makanan padat. Apabila makanan padat tidak diberikan pada saat itu, bayi akan mengalami kekurangan gizi karena ASI/susu formula saja sudah tidak dapat memenuhi seluruh kebutuhan gizi bayi pada saat itu. Sebaliknya pemberian MP-ASI terlalu dini dapat menimbulkan gangguan pada pencernaan seperti diare, muntah dan sulit buang air besar (Angkat, 2018).

Hasil analisis multivariat ditemukan hubungan antara riwayat penyakit infeksi dengan kejadian stunting dengan OR 3,69 (95\%CI:2,126,43), setelah dikontrol variabel Akses ke jamban sehat, Akses ke sumber air bersih, Riwayat penyakit infeksi dan riwayat pemantauan pertumbuhan.

Penelitian ini juga sesuai dengan penelitian lain yang mengemukakan bahwa pemberian MPASI yang tepat merupakan faktor protektif terhadap kejadian balita gizi buruk (Susanty, 2012). Penelitian pada anak balita di Turki menunjukkan bahwa pemberian MP-ASI terlalu dini merupakan faktor risiko terjadinya stunting (Ergin, 2007). Anak usia anak 12-36 tahun merupakan masa pertumbuhan yang sangat cepat, apabila pada usia tersebut anak tidak mendapatkan asupan dalam jumlah yang cukup dan jenis yang bervariasi mengakibatkan kekurangan nutrisi yang dibutuhkan pada masa pertumbuhan sehingga anak mengalami keterlambatan pertumbuhan (Angkat, 2018).

\section{Riwayat Pemantauan Pertumbuhan}

Pemantauan perkembangan balita sangat perlu dipantau agar jika terjadi ke abnormalan akan lebih dini dapat terdeteksi, karena perkembangan pada masa balita sangat menentukan perkembangan masa selanjutnya, pada masa ini pertumbuhan dasar yang akan mempengaruhi dan menentukan perkembangan anak selanjutnya. Pada masa ini perkembangan kemampuan berbahasa, kreativitas, kesadaran sosial, emosional dan intelegensia berjalan sangat cepat dan merupakan landasan perkembangan berikutnya, NGr, S. (2012). Penelitian ini menemukan hubungan antara Riwayat Pemantauan Pertumbuhan dengan kejadian stunting dengan OR 10,16 (95\%CI:5,16-20,02), setelah dikontrol variabel akses ke jamban sehat, akses ke sumber air bersih, riwayat penyakit infeksi dan riwayat pemberian MP-ASI. Penelitian ini sejalan dengan penelitian yang dilakukan oleh Marume (2019) menyatakan 
bahwa monitoring pertumbuhan yang dilakukan secara rutin dapat menurunkan kejadian malnutrisi khususnya stunting. Selanjutnya menurut Marume bahwa monitoring pertumbuhan yang dilakukan dapat mendeteksi kejadian stunting.

\section{SIMPULAN}

Penelitian ini melaporkan terdapat dua faktor lingkungan yang secara bersama-sama

\section{DAFTAR PUSTAKA}

Almatsier, S. (2013). Prinsip Dasar Ilmu Gizi Edisi 9. Jakarta: PT. Gramedia Pustaka Utama.

Angkat, A. H. (2018). Penyakit Infeksi dan Praktek Pemberian MP-ASI Terhadap Kejadian Stunting Pada Anak Usia 12-36 Bulan di Kecamatan Simpang Kiri Kota Subulussalam. Jurnal Dunia Gizi, 1(1), 5258.

Antika, R., \& Budiastutik, I. (2018). Sosial Ekonomi, Berat Lahir Dan Penyakit Infeksi ngan Kejadian Stunting Pada Balita di Desa Semanga Kecamatan Sejangkung Kabupaten Sambas. Jurnal Kesmas (Kesehatan Masyarakat) Khatulistiwa, 1(1), 35-46.

Azmii, F., \& Arini, F. A. (2018). Karakteristik Ibu, Riwayat Asi Eksklusif Dan Riwayat Penyakit Infeksi Dengan Kejadian Stunting Pada Balita 12-59 Bulan Di Wilayah Kerja Puskesmas Sukmajaya. Medika Respati, 13(4).

Badan Pusat Statistik (BPS). (2017). Statistik Kesejahteraan Rakyat Tahun 2017. Jakarta.

Basuki, B. (2000). Aplikasi metode kasus kontrol. Jakarta: Fakultas Kedokteran Universitas Indonesia.

Checkley, W., Gilman, R. H., Black, R. E., Epstein, L. D., Cabrera, L., Sterling, C. R., \& Moulton, L. H. (2004). Effect of water and sanitation on childhood health in a poor Peruvian peri-urban community. The Lancet, 363(9403), 112-118.

Dinas Kesehatan Kabupaten Lampung Timur. (2017). Laporan pemantauan status gizi balita tahun 2017. Sukadana: Dinas Kesehatan Kabupaten Lampung Timur.

Ergin, F., Okyay, P., Atasoylu, G., \& Beser, E. (2007). Nutritional status and risk factors of chronic malnutrition in children under five years of age in Aydin, a western city berhubungan dengan kejadian stunting pada anak usia enam sampai 59 bulan, yaitu akses ke jamban sehat dan akses ke sarana air bersih. Perlu adanya pengendalian faktor risiko kejadian stunting dilakukan peningkatan akses ke jamban keluarga dan sarana air bersih yang memenuhi syarat kesehatan, melakukan penyuluhan terutama ibu balita terkait pencegahan penyakit infeksi dan sanitasi lingkungan.

of Turkey. Turkish Journal of Pediatrics, 49(3), 283.

Fink, G., Günther, I., \& Hill, K. (2011). The effect of water and sanitation on child health: evidence from the demographic and health surveys 1986-2007. International journal of epidemiology, 40(5), 1196-1204.

Hafid, F., \& Djabu, U. (2018). Efek Program SBABS Terhadap Pencegahan Stunting Anak Baduta di Kabupaten Banggai dan Sigi. Indonesian Journal of Human Nutrition, 4(2), 79-87.

Kementerian Kesehatan RI. (2018). Buku saku pemantauan status gizi tahun 2017. Jakarta: Kementerian Kesehatan Republik Indonesia.

Kementerian Kesehatan RI. (2011). Keputusan Menteri Kesehatan Republik Indonesia Nomor: 1995/Menkes. SK/XII/2010 Tentang Standar Antropometri Penilaian Status Gizi Anak. Jakarta: Direktorat Jenderal Bina Gizi dan Kesehatan Ibu dan Anak.

Lin, A., Arnold, B. F., Afreen, S., Goto, R., Huda, T. M. N., Haque, R.,. \& Luby, S. P. (2013). Household environmental conditions are associated with enteropathy and impaired growth in rural Bangladesh. The American journal of tropical medicine and hygiene, 89(1), 130-137.

Marume, A., Mafaune, P., Maradzika, J., \& January, J. (2019). Evaluation of the childgrowth-monitoring programme in a rural district in Zimbabwe. Early Child Development and Care, 189(2), 318-327.

Nasikhah, R., \& Margawati, A. (2012). Faktor risiko kejadian stunting pada balita usia 24-36 bulan di Kecamatan Semarang Timur. [Skripsi]. Semarang: Fakultas Kedokteran, Universitas Diponegoro.

Proverawati, A., \& Asfuah, S. (2009). Buku ajar gizi untuk kebidanan. Jakarta. 
Prendergast, A. J., \& Humphrey, J. H. (2014). The stunting syndrome in developing countries. Pediatrics and international child health, 34(4), 250-265.

Rah, J. H., Cronin, A. A., Badgaiyan, B., Aguayo, V. M., Coates, S., \& Ahmed, S. (2015). Household sanitation and personal hygiene practices are associated with child stunting in rural India: a cross-sectional analysis of surveys. BMJ Open, 5(2), e005180.

Riset Kesehatan Dasar. (2013). Riskesdas 2013. Jakarta: Badan Litbang Kesehatan.

Soetjiningsih, I. G. (2012). N. Gde Ranuh. Tumbuh Kembang Anak.. Jakarta: EGC.

Supariasa, I. D. N., Bakri, B., \& Fajar, I. (2002). Penilaian status gizi. Jakarta: EGC.

Susanty, M., Kartika, M., Hadju, V., \& Alharini, S. A. (2012). Hubungan pola pemberian ASI dan MP-ASI dengan gizi buruk pada anak 6-24 bulan di Kelurahan Pannampu
Makassar. Media gizi masyarakat indonesia, 1(2), 97-103.

Tim Nasional Percepatan Penanggulangan Kemiskinan. (2017). 100 kabupaten/ kota prioritas untuk intervensi anak kerdil (stunting). Jakarta.

Torlesse, H., Cronin, A. A., Sebayang, S. K., \& Nandy, R. (2016). Determinants of stunting in Indonesian children: evidence from a cross-sectional survey indicate a prominent role for the water, sanitation and hygiene sector in stunting reduction. $B M C$ Public Health, 16(1), 669.

Van der Hoek, W., Feenstra, S. G., \& Konradsen, F. (2002). Availability of irrigation water for domestic use in Pakistan: its impact on prevalence of diarrhea and nutritional status of children. Journal of Health, Population and Nutrition, 77-84.

World Health Organization. (2016). Results of round I of the WHO International Scheme to evaluate household water treatment technologies. 